\title{
Semantyka i metodyka oceny georóżnorodności - przegląd i propozycja badawcza
}

\author{
Semantics and geodiversity assessment methods - review and research proposal
}

\author{
Alicja Najwer, Zbigniew Zwoliński \\ Instytut Geoekologii i Geoinformacji, Uniwersytet im. Adama Mickiewiczaw Poznaniu, e-mail: alijas@amu.edu.pl
}

Zarys treści: Koncepcja georóżnorodności została opracowana stosunkowo niedawno, aczkolwiek bardzo szybko zyskała aprobatę naukowców na całym świecie. Jest to jednak wczesna faza rozpoznania problemu i w efekcie, pojęcie to nadal nie jest jednoznacznie rozumiane i definiowane. Niewielkie postępy zostały też poczynione w badaniach nad metodyką jej oceny oraz geowizualizacji. Istnieje wyraźna potrzeba stworzenia powszechnie akceptowanej metody oceny georóżnorodności. Głównym celem artykułu jest przedstawienie aktualnych koncepcji georóżnorodności oraz dotychczasowych dokonań w zakresie metodyki jej oceny. Przegląd ten, stanowić winien naukowe tło do prowadzenia szeroko zakrojonych, dalszych badań nad uniwersalną i przejrzystą metodyką oceny georóżnorodności. W przyszłości da to szansę jej szerokiej implementacji w wielu dziedzinach nauki. Ponadto w niniejszym artykule zaprezentowano nową metodę oceny georóżnorodności. Podstawą algorytmu analitycznego jest dobór odpowiednich cech środowiska przyrodniczego i parametrów geomorfometrycznych. Przygotowane mapy czynnikowe są poddawane standaryzacji, a następnie analizie wielokryterialnej przy wykorzystaniu metody hierarchicznej analizy procesów decyzyjnych. Obszar badań stanowi 5 zlewni rzecznych zlokalizowanych w Polsce i w Szwajcarii. Cztery z nich to zlewnie charakteryzujące się krajobrazem wysokogórskim: Derborence oraz Illgraben w Alpach Szwajcarskich, Sucha Woda w Tatrach oraz Wrzosówka w Karkonoszach. Zlewnia Dębnicy znajduje się na Niżu Polskim.

Słowa kluczowe: georóżnorodność, geoochrona, ocena georóżnorodności, mapy georóżnorodności

\begin{abstract}
The concept of geodiversity was created recently and has rapidly gained the approval of scientists around the world. However, the problem recognition is still at an early stage. Moreover, little progress has been made concerning its assessment and geovisualisation. Yet, the lack of a commonly accepted methodology is clearly noticeable. The main purpose of this paper is to present the current state of understanding the geodiversity concepts, discuss some research approaches and achievements in the field of its assessment methods. An overview should be found as a scientific framework for conduction of further studies especially focusing on establishing a commonly accepted and transparent assessment methodology. It will give an opportunity for its broad implementation across numerous disciplines. Furthermore a proposal of a new method of geodiversity assessment is presented. The basis for the assessment is a proper selection of the geographical environment features and geomorphometric parameters. Prepared factor maps are being standardized and resulted from map algebra operations carried out by multi-criteria evaluation with GIS-based analytic hierarchy process. The study areas consist of 5 peculiar catchments in Poland and Switzerland. Four are located in the high mountainious landscape (Derborence and Illgraben in the Swiss Alps, Sucha Woda in the Tatra Mts., and Wrzosówka in the Karkonosze Mts.) and one (Dębnica catchment) in the Polish Lowland area.
\end{abstract}

Key words: geodiversity, geoconservation, geodiversity assessment, geodiversity mapping

\section{Wstęp}

Wzrost świadomości społecznej oraz rosnące zainteresowanie środowiskiem przyrodniczym i jego ochroną stwarza potrzebę szerokiego zrozumienia i propagowania pojęcia georóżnorodności. Szczególnie jest to istotne w przypadku obszarów podlegających intensywnym przemianom naturalnym bądź antropogenicznym (Prosser $i$ in. 2010). $Z$ uwagi na obserwowane ostatnimi laty zmiany klimatyczne i w ich konsekwencji nasiloną działalnością zjawisk o charakterze ekstremalnym (Jania, Zwoliński 2011), a nawet katastrofalnym (IPCC 2007) oraz w wyniku lokalnych przekształceń pokrycia terenu i użytkowania ziemi, abiotyczna heterogeniczność obsza- 
rów lądowych może zostać poważnie zagrożona, a kluczowe elementy różnorodności nawet utracone (Gordon i in. 2002, Gray 2004, Ruban 2010, Hjort, Luoto 2012). Niezwykle ważne jest więc rozpoznanie stanu aktualnego georóżnorodności, gdyż rzutuje ona na prognozę zmian zachodzących w środowisku, a przede wszystkim umożliwia ocenę przydatności warunków przyrodniczych do pełnienia określonych funkcji (Richling, Solon 2011). Nowe geotechnologie pozyskiwania i przetwarzania danych przestrzennych, dają obecnie szerokie możliwości do wykonywania specjalistycznych analiz geoinformacyjnych. W tym kontekście pierwszoplanowym problemem jest obiektywna ocena zmian krajobrazowych oraz ich kartograficzna wizualizacja poprzez analizę georóżnorodności. Jak dotąd w literaturze, nie zaproponowano uniwersalnej metody oceny georóżnorodności, która mogłaby być stosowana z pozytywnymi rezultatami zarówno dla obszarów o zróżnicowanym typie krajobrazu, jak i skali przestrzennej. Celem artykułu jest przedstawienie aktualnych koncepcji georóżnorodności oraz dotychczasowych dokonań w zakresie metodyki jej oceny, jako naukowego tła do prowadzenia, jakże istotnych, dalszych badań nad georóżnorodnością i ustanowienia standardów metodologicznych i metodycznych jej właściwego rozpoznania.

\section{Koncepcja i definicja georóżnorodności}

W 1992 roku w Rio de Janeiro odbył się Szczyt Ziemi Konferencja Narodów Zjednoczonych dotycząca Środowiska i Rozwoju, wprowadzająca w powszechne użycie koncepcję bioróżnorodności. W kręgach najpierw geologów, a potem również geografów, pojawiły się na świecie nowe idee związane ze zrównoważonym rozwojem oraz zasadami zapobiegania degradacji środowiska przyrodniczego. $Z$ tymi działaniami oraz w odpowiedzi na znacznie lepiej rozpoznaną w literaturze koncepcję bioróżnorodności (popartą Konwencją o Różnorodności Biologicznej), związane są narodziny nowej koncepcji postrzegania i rozumienia środowiska abiotycznego - georóżnorodności (Gray 2004).

Po raz pierwszy pojęcie georóżnorodności pojawiło się w literaturze niemieckojęzycznej (niem. Geodiversität) w pracy Wiedenbein'a (1993) i w szerszym kontekście tyczyło się problematyki geostanowisk (geotopów) i geoochrony. Do literatury anglojęzycznej, również w 1993 roku, termin ten (ang. geodiversity) wprowadził Sharples (1993, za Gray 2013). Niezwykle szybko pojęcie georóżnorodności zyskało aprobatę naukowców na całym świecie. Ciągle jednak jest to wczesna faza rozpoznania problemu i w efekcie, pojęcie to nadal nie jest jednoznacznie rozumiane i definiowane.

W literaturze przedmiotu zarówno polskiej jak i światowej występuje wiele kontekstów badań nad georóżnorodnością, jej rozumienia i rozpatrywania. Mizgajski (2001) wyróżnił trzy główne podejścia badawcze: geologiczne, kompleksowe oraz traktujące zróżnicowanie elementów abiotycznych środowiska przyrodniczego jako podstawy do analiz bioróżnorodności. Miśkiewicz (2009) wyodrębnił aż siedem aspektów badań nad georóżnorodnością, jej rozumienia oraz rozpatrywania $\mathrm{w}$ zależności od zakresu i celu przeprowadzonych badań. Te siedem aspektów badań jednak, zdaniem autorów jest nietrafnych i tracą one na walorze porządkującym przede wszystkim ze względu na nieostry zakres pojęciowy charakteryzujący poszczególne koncepcje. Niektóre z przytoczonych przez tego autora odniesień literaturowych można by przyporządkować do kilku rozpoznanych aspektów i z tego też powodu nie został tutaj uwzględniony. Poniżej przedstawione zostały uaktualnione koncepcje badań georóżnorodności na podstawie podziału Mizgajskiego (2001).

Pierwsza, koncepcja geologiczna rozwinęła się za sprawą badań geologów i geomorfologów australijskich (Sharples 1993, 1995, Kiernan 1995, 1996, Dixon 1996, Eberhard 1997) i odnosi się głównie do ochrony litosfery (geoochrona). Jedna z pierwszych roboczych definicji została sformułowana przez Sharples'a (1993, s.7), gdzie georóżnorodność rozumiana była jako zróżnicowanie cech (obiektów) i systemów ziemskich. W późniejszych swoich pracach $(1995$, s. 38, 2002, s. 6) autor sformułował pełniejszą definicję: georóżnorodność to zakres (zróżnicowanie) obiektów geologicznych (podłoża), geomorfologicznych (form rzeźby) oraz pokrywy glebowej, ich zespolów, systemów oraz zachodzacych między nimi procesów. Jest to definicja prosta w swojej formule, ale i szeroko ujmująca problem badawczy (Pellitero i in. 2014). Sformułowanie to pośrednio obejmuje także procesy hydrologiczne i klimatyczne (atmosferyczne), oczywiście o ile wywierają one jakikolwiek wpływ na właściwości geologiczne, glebowe i rzeźbę obszaru (Sharples 2002). Definicja ta z niewielkimi przekształceniami została przyjęta przez Australian Heritage Commision (1996, 2002) i podana w Encyklopedii Geomorfologii (Zwoliński 2004) oraz zmodyfikowana przez Graya (2004, 2013). Ta ostatnia można stwierdzić, iż jest jedną z najbardziej spopularyzowanych definicji georóżnorodności na świecie. Podobnie jak w Australii koncepcja georóżnorodności rozumiana jest wśród badaczy brytyjskich (Prosser 2002, Gray 2004, 2008, 2013, Burek, Potter 2006, Prosser i in. 2010, Gordon, Barron 2011, 2013, Gordon 2012, Gordon i in. 2012, Gray i in. 2013).

Wraz z rozwojem badań nad różnorodnością biologiczną, zwrócono także uwagę na szczególną zależność bioróżnorodności od georóżnorodności. Duff (1994) w swoim artykule określał georóżnorodność jako różnorodność abiotyczną. Stwierdził, iż pewne elementy geologiczne podłoża mają swoje odzwierciedlenie w bogactwie oraz różnorodności gatunkowej roślin na danym obszarze badań. Podobnie georóżnorodność, jako podstawa do analiz prowadzonych nad bioróżnorodnością, traktowana jest w badaniach niemieckich (Leser 1997, Barthlott i in. 1999, Jedicke 2001). Jedicke (2001, s. 60) definiuje georóżnorodność jako zmienność składników i komponentów abiotycznych $w$ hierarchicznym systemie ekologicznym takich jak: rzeźba terenu, budowa geologiczna, pokrywa 
glebowa, wody powierzchniowe i podziemne oraz atmosfera (w możliwie najbardziej równorzędnej formie). Tworza one funkcjonujace przestrzennie systemy relacyjne (fizjotopy) $i$ wspólnie z bioróżnorodnościa - ekosystem. Zróżnicowanie subsystemu abiotycznego, było traktowane pobocznie, zazwyczaj jako pewna zmienna pomocnicza. W ostatniej dekadzie, coraz chętniej jednak, podejmowane są problemy badawcze gdzie punktem wyjścia jest georóżnorodność, zintegrowana z siedliskami naturalnymi oraz krajobrazem (Silva 2004, Jačková, Romportl 2008, Alexandrowicz, Margielewski 2010, Parks, Mulligan 2010, Virtanen i in. 2010, Pellitero i in. 2010, Hjort $\mathrm{i}$ in. 2012, Kistowski 2012). Georóżnorodność oraz bioróżnorodność składają się na różnorodność naturalną (Serrano, Ruiz-Flaño 2009), dlatego też ta koncepcja badawcza winna być określana jako koncepcja różnorodności naturalnej.

W kompleksowym podejściu badawczym georóżnorodność jest znacznie szerzej charakteryzowana niż w koncepcji geologicznej, system biotyczny nie jest tak manifestowany jak w konotacji różnorodności naturalnej, a dodana natomiast została obecność i działalność człowieka. Słusznie wielu badaczy (Mizgajski 2001, Gray 2004, 2013, Kot 2006a, Miśkiewicz 2009, Serrano, Ruiz-Flaño 2009, Migoń 2012) łączy rozwój tego kierunku z badaniami polskimi, za sprawą wypracowanych podstaw koncepcji przez Kozłowskiego (1997) oraz Kostrzewskiego (1998). Georóżnorodność była ściśle powiązana z działalnością na rzecz ochrony litosfery, a jej początkowe definiowanie (Kozłowski 1997, s. 489) nie było zbyt udane (Migoń 2012). Znacznie trafniej zakres pojęciowy określił Kostrzewski (1998, s. 13): georóżnorodność obejmuje zróżnicowanie powierzchni Ziemi $w$ zakresie budowy geologicznej, rzeźby, klimatu, wód powierzchniowych i podziemnych z uwzględnieniem oddziaływania człowieka. Szczególnie geoochrona znalazła swój wyraz w licznych opracowaniach lub projektach badawczych realizowanych przez Państwowy Instytut Geologiczny - Państwowy Instytut Badawczy, np. w postaci Mapy geologiczno-gospodarczej Polski w skali 1:50 000 (wydawana w latach 1997-2007), Mapy geośrodowiskowej Polski w skali 1:50 000 (wydawana w latach 20022012), opracowań i map chronionych i proponowanych do ochrony obszarów i obiektów przyrody nieożywionej (polskie Karpaty - Alexandrowicz, Poprawa 2000, Dolny Śląsk - Gawlikowska 2000, region świętokrzyski - Wróblewski 2000, województwo małopolskie - PGI 2011), artykułów (Alexandrowicz 2003, 2004, 2006, 2007, Kozłowski i in. 2004) oraz internetowego Centralnego Rejestru Geostanowisk Polski (PGI 2014). Koncepcja kompleksowa badań georóżnorodności nie jest tylko domeną polską i coraz częściej pojawia się w literaturze światowej (Stanley 2001, Serrano, Ruiz-Flaño 2007, 2009). Wielu badaczy jednak absolutnie świadomie odrzuca obecność i działalność człowieka z definicji georóżnorodności, argumentując, że czynnik antropogeniczny osłabia tak szeroko zakrojoną koncepcję, nie posiadającą aplikacyjnego zastosowania (Pereira i in. 2013).
Georóżnorodność może być również charakteryzowana indywidualnie, jako zróżnicowanie w obrębie poszczególnych sfer powierzchni Ziemi (Kostrzewski 1998, Degórski 2001, Kot 2006a), jak np. gleb (ang. pedodiversity) (Zhang i in. 2003, Saldaña, Ibáñez 2004, Kot 2006a, Krasilnikov i in. 2009, Ibáñez i in. 2012), form powierzchni terenu (ang. geomorphodiversity, landform geodiversity) (Kostrzewski 1998, 2011, Nichols i in. 1998, Kot 2005c, Panizza 2009, 2011, Zwoliński 2009, 2010, Testa i in. 2013, Najwer, Zwoliński 2015), czy też skał (ang. lithodiversity) (Mihalasky, Bonham-Carter 2001).

Pojęcie georóżnorodności, szczególnie w literaturze polskiej często jest błędnie interpretowane i mylone $\mathrm{z}$ innymi, nowymi terminami związanymi $\mathrm{z}$ ochroną przyrody nieożywionej jak np.: geoochrona (ang. geoconservation), geoturystyka (ang. geoturism), dziedzictwo Ziemi (ang. geoheritage) i geostanowisko (ang. geosite) itp. Celem autorów nie jest opis poszczególnych definicji powyższych terminów, ponieważ niejednokrotnie były one już przytaczane w literaturze przedmiotu. Pragną jednak zwrócić uwagę na pewne powtarzające się błędy merytoryczne. Dziedzictwo Ziemi (ang. geoheritage) to zarówno dziedzictwo geologiczne jak i geomorfologiczne i nie jest pojęciem tożsamym z georóżnorodnością jak np. twierdzi Gonera (2005). Terminy te pomimo, iż mają ze sobą wiele wspólnego, różnią się przede wszystkim wyznacznikiem czasowym. Pojęcie georóżnorodności odnosi się przede wszystkim do teraźniejszości i zawiera komponent dynamiczny, podczas gdy dziedzictwo Ziemi obejmuje raczej statyczny i zachowany do dnia dzisiejszego zapis przeszłości (Migoń 2012). Pojęcie georóżnorodności w literaturze polskiej wydaje się być nadużywane. W wielu opracowaniach (m.in. Alexandrowicz, Poprawa 2000, Gawlikowska 2000, Wróblewski 2000, Sidorczuk, Ścibisz-Kosanowska 2013) pojawia się nawet w samym tytule, pomimo iż treść odnosi się do ochrony przyrody nieożywionej (ang. geoconservation) ze szczególnym uwzględnieniem litosfery, a nie do szeroko zakrojonej pojęciowo georóżnorodności.

\section{Mapy i indeksy georóżnorodności}

Nieodzownym warunkiem sporządzenia poprawnego planu zagospodarowania przestrzennego z uwzględnieniem różnych form ochrony przyrody, zarządzania obszarami chronionymi lub delimitacji nowych, do zachowania i ochrony, jest posiadanie pełnego rozpoznania walorów przyrodniczych danego terenu. Ogólnie ujmując, niezbędne jest przeprowadzenie ewaluacji zróżnicowania abiotycznego i biotycznego przedmiotowego obszaru. Bioróżnorodność posiada już ugruntowane metody oceny i nie są one rozważane w tym artykule.

$\mathrm{Na}$ gruncie nauk geograficznych ocenę środowiska przyrodniczego można utożsamiać z wartościowaniem, a więc określaniem znaczenia i przypisywaniem zalet komponentom środowiska przyrodniczego (Bródka 2010, Macias, Bródka 2014). Autorzy podkreślają, iż 
przenoszenie oceny na skalę porównawczą to waloryzacja. W szeroko pojętej geografii waloryzację środowiska przyrodniczego przeprowadza się przy uwzględnieniu dwóch podejść metodycznych: analitycznego oraz kompleksowego (Bródka 2010, Macias, Bródka 2014). Pierwsze nawiązuje do tzw. redukcjonizmu naukowego, który opiera się na założeniu, iż wnioskowanie odnośnie całości jest możliwe poprzez sprowadzenie jej do prostej sumy części składowych, przy jednoczesnym zminimalizowaniu znaczenia procesów i relacji zachodzących między nimi. Wynik końcowy waloryzacji jest połączeniem ocen cząstkowych i map analitycznych, które składają się na syntetyczny obraz końcowy. To podejście metodyczne jest najbardziej rozpropagowane wśród dotychczasowych ocen georóżnorodności. W podejściu kompleksowym uwaga skoncentrowana jest na oddziaływaniach pomiędzy poszczególnymi elementami (komponentami środowiska przyrodniczego). Zmienne, które charakteryzują się największą mocą wyjaśniającą traktowane są jako przewodnie w stosunku do pozostałych.

Ocena właściwa, po dokonaniu czynności wstępnych, według Bartkowskiego (1977) składa się z dwóch etapów: bonitacji i kwalifikacji. Bonitacja w naukach geograficznych jest to ilościowe lub jakościowe wartościowanie składników i cech struktury środowiska przyrodniczego. Ostatecznym jej etapem jest kwalifikacja, a więc zaliczenie rozpatrywanych zjawisk fizycznogeograficznych lub też obiektów do pewnej kategorii i określenie ich jakości (Sołowiej 1992). Gonera $(2005,2008)$ uważa, iż za pomoca georóżnorodności nie można waloryzować obszarów, gdyż nie istnieje żadna ilościowa jednostka miary, którą można by uznać za obiektywną, jak np. w przypadku oceny bioróżnorodności - liczba wszystkich gatunków znajdujących się na określonym terytorium, a szacunki wartości georóżnorodności przedstawiane są jedynie na podstawie arbitralnych decyzji lub subiektywnej oceny. Autorzy tego artykułu, jak i wielu innych badaczy dokonujących oceny georóżnorodności, stoją w opozycji do stanowiska Gonery.

W literaturze przedmiotu, szczególnie w ostatniej dekadzie, pojawiło się wiele prób waloryzacji georóżnorodności i przedstawiania jej wartości na mapach w różnej skali przestrzennej. Zazwyczaj jest to skala lokalna lub regionalna, aczkolwiek takie analizy możliwe są do wykonania także dla dużych jednostek przestrzennych jak np. obszar całego państwa (Zwoliński 2007, Benito-Calvo $i$ in. 2009, Pereira i in. 2013).

Dotychczas, najpopularniejszą metodą ilościową waloryzacji zróżnicowania abiotycznych komponentów środowiska przyrodniczego są indeksy georóżnorodności. Za ich pomocą określana jest liczbowo wartość dla każdego z przyjętych pól podstawowych oceny (Burnett $i$ in. 1998, Nichols i in. 1998, Silva 2004, Zwoliński 2007, 2009, Melelli 2014). Burnett i in. (1998) oraz Nichols i in. (1998) byli jednymi z pierwszych badaczy, którzy podjęli się oceny oraz geowizualizacji georóżnorodności. Burnett $i$ in. (1998) oraz Nichols i in. (1998) wykorzystali w tym celu metodę opartą na wskaźniku różnorodności Sha-
nona-Weavera, który to $\mathrm{z}$ powodzeniem stosowany jest w badaniach bioróżnorodności. Niestety pierwsze próby nie ujmowały w pełni koncepcji georóżnorodności, a odnosiły się głównie do zbadania zależności pomiędzy bioróżnorodnością a zróżnicowaniem geomorfologicznym.

Większość ewaluacji georóżnorodności przy zastosowaniu indeksów opartych jest na koncepcji opublikowanej pierwotnie przez Serrano oraz Ruiz-Flaño (2007, Serrano i in. 2009, Hjort, Luoto 2010, Pellitero i in. 2010, 2014, Comanescu, Nedelea 2012, Kot 2012). Indeks georóżnorodności obliczany jest według poniższego wzoru (Serrano, Ruiz-Flaño 2007, 2009, Serrano i in. 2009):

$$
\mathrm{Gd}=\mathrm{Eg} \mathrm{R} / \ln \mathrm{S}
$$

gdzie:

Gd - indeks georóżnorodności,

Eg - liczba elementów środowiska przyrodniczego w polu podstawowym,

R - współczynnik szorstkości (chropowatości) w polu podstawowym,

ln - logarytm naturalny,

$\mathrm{S}$ - powierzchnia pola podstawowego $\left(\mathrm{km}^{2}\right)$.

Metodyka zaproponowana przez Serrano oraz RuizFlaño (2007) została wypracowana dla Tiermes-Caracena, obszaru zlokalizowanego w centralnej Hiszpanii. Teren ten charakteryzuje się znacznie większą energią rzeźby niż obszary nizinne i zaproponowane przez autorów przedziały klas spadku, używanego w celu obliczenia zmiennej szorstkości terenu, nie są uniwersalne dla dowolnego obszaru badań (Kot 2012). W związku z czym, sposób oszacowania tego właśnie parametru w postępowaniu badawczym jest często modyfikowany (Hjort, Luoto 2010, Pellitero i in. 2010), bądź nawet eliminowany (Pellitero $\mathrm{i}$ in. 2014, Comanescu, Nedelea 2012).

Wartość georóżnorodności oceniana jest również przy wykorzystaniu techniki bonitacji punktowej (ilościowej oraz jakościowej). Metoda ta dotychczas znajdowała zastosowanie głównie w badaniach polskich naukowców (Kostrzewski i in. 1997a, b, 1998a, b, Kot 2005a, b, c, 2006a, b, 2014, Kot, Szmidt 2010, Radwanek-Bąk, Laskowicz 2012), aczkolwiek z częściowymi modyfikacjami. Metody bonitacyjne można znaleźć także w literaturze zagranicznej (Jačková, Romportl 2008, Hjort, Luoto 2012, Hjort i in. 2012, Pereira i in. 2013). Bonitacja punktowa z powodzeniem stosowana jest także do oceny atrakcyjności geoturystycznej obszarów i geostanowisk (Reynard i in. 2007, Pereira i in. 2007, 2013, Zwoliński 2010, Silva i in. 2013). Według Richlinga (1992) jest to najprostsza metoda ilościowa przedstawiania zróżnicowania środowiska przyrodniczego. Polega ona na przypisywaniu analizowanym cechom wartości punktowych w naturalnych, bądź sztucznie ustanowionych polach podstawowych. Czynność ta poprzedzona jest sprawiającą największe problemy typologią - ustaleniem szeregów bonitacyjnych dla danej kategorii oceny (Sołowiej 1992). Przypisane wartości punktowe są następnie sumowane dla każdego z pól podstawowych waloryzacji. Wynik fi- 
nalny bonitacji najczęściej przedstawiany jest na mapie w postaci kartogramu.

Technikę bonitacji punktowej w polskich badaniach georóżnorodności po raz pierwszy zaproponowali Kostrzewski i in. (1997a, b, 1998a, b), a następnie szerzej stosował Kot (2005a, b, c, 2006a, b, 2014). Opracowanie metodyczne oceny georóżnorodności, ostatni z autorów przeprowadził na obszarze testowym tj. fragmencie fordońskiego odcinka doliny dolnej Wisły oraz jej otoczenia (Kot 2005a, b, c, 2006a, b), zatem obszarze typowym dla krajobrazu młodoglacjalnego Niżu Polskiego. Pod rozwagę wziął następujące abiotyczne komponenty środowiska przyrodniczego: budowę geologiczną, rzeźbę terenu, typy gleb, wody powierzchniowe oraz klimat. Jest to najbardziej obszerne opracowanie metodyczne oceny wartości georóżnorodności w literaturze polskiej. Dotychczas jednak metoda ta, chociaż prosta w założeniach, nie znalazła wielu przykładów zastosowań. Nie spełniła także, założonego przez autora celu aplikacyjnego, tj. delimitacji obszarów cennych przyrodniczo.

Zwoliński (2007, 2008, 2009) zaproponował ocenę georóżnorodności, która częściowo nawiązuje do ilościowej bonitacji punktowej, ale przede wszystkim wyróżnia ją, spośród wszystkich przedstawionych tutaj metod oceny, wykorzystanie systemu eksperckiego. Mapy georóżnorodności rzeźby (Zwoliński 2007, 2008, 2009), powstały w wyniku zastosowania metody bonitacji punktowej i były wypadkową 3 map czynnikowych: energii rzeźby (lokalna wysokość względna), fragmentacji terenu, utworzonej na podstawie mapy geomorfologicznej oraz mapy współczesnego zachowania rzeźby, uzyskanej z przetworzenia bazy danych CORINE Land Cover. Wartości każdego z pól oceny pierwszej mapy zreklasyfikowano do 5 klas, metodą podziału naturalnego Jenksa (ang. natural breaks), dwóch pozostałych przy wykorzystaniu wiedzy eksperckiej.

Najbardziej kompleksowe ujęcie metodyczne oceny georóżnorodności zaproponowali Zwoliński, Stachowiak (2012). Jako obszar badań autorzy ci obrali jeden z najbardziej charakterystycznych i wyrazistych obszarów w Polsce pod względem geomorfologicznym - Tatrzański Park Narodowy. W celu wygenerowania mapy georóżnorodności autorzy wykorzystali aż 11 cech abiotycznych komponentów środowiska przyrodniczego: budowę geologiczną obszaru, jaskinie, fragmentację rzeźby terenu, energię rzeźby terenu (lokalna wysokość względna), spadki terenu, jeziora, źródła, cieki, wodospady, gleby oraz piętra geoekologiczne. Większość warstw została przeklasyfikowana z wykorzystaniem metody naturalnej przerwy, a w przypadku elementów jakościowych środowiska przyrodniczego, wykorzystano wiedzę ekspercką na podstawie konsultacji, doświadczenia autorów oraz literatury przedmiotu. Wartości punktowe każdej z map czynnikowych zostały zsumowane w polach oceny i następnie zreklasyfikowane do 5 klas wartości georóżnorodności. Dużym problemem, w zastosowaniu tej metody na innych obszarach badawczych, mogą być dane źródłowe. Technika oceny georóżnorodności została opracowana dla obszaru parku narodowego, a więc jednostki, która statutowo zobowiązana jest do gromadzenia i udostępniania danych o środowisku przyrodniczym. Niestety dla większości terenów dane te będzie trzeba zebrać i zintegrować autonomicznie, co może okazać się bardzo pracochłonne, a czasem nawet niemożliwe do osiągnięcia. Metoda ta, w nieco zmodyfikowanej formie, została wykorzystana dla oceny georóżnorodności dwóch dolin zlokalizowanych w Alpach Szwajcarskich: Derborence oraz Illgraben (Jaskulska i in. 2013) oraz dla zlewni Dębnicy (Mazurek i in. 2015).

Istnieją w literaturze przedmiotu także próby oceny georóżnorodności za pomocą miar krajobrazowych, które najogólniej można podzielić na: miary rozdrobnienia, miary powiązań i zależności oraz miary kształtowe. Stosowanie takich wskaźników jest stosunkowo popularne w badaniach dotyczących struktury krajobrazu i użytkowania ziemi lub bioróżnorodności, aczkolwiek próba ich wykorzystania do oceny georóżnorodności, jak sami autorzy zauważają jest raczej problematyczna (Kot, Leśniak 2006, Malinowska, Szumacher 2013). Do znacznie bardziej optymistycznych wniosków doszli Benito-Calvo i in. (2009). Stwierdzili, że miary krajobrazowe są przydatne w ocenach georóżnorodności np. w celu przeprowadzenia analizy porównawczej obszarów do siebie podobnych pod względem cech środowiska przyrodniczego oraz rozdzielczości przestrzennej.

Podsumowując, stan zaawansowania badań w kwestii oceny georóżnorodności należy nadal uznać jako początkowy. Pomimo, iż sama koncepcja georóżnorodności, posiada solidne podstawy teoretyczne, nie powstała dotychczas uniwersalna metoda jej oceny. Jedynie ustalenie powszechnie akceptowanej i przejrzystej metodyki waloryzacji georóżnorodności, da szansę jej szerokiej implementacji w wielu dziedzinach nauki, zarządzania i gospodarowania przestrzenią geograficzną. Georóżnorodność wówczas, może stać się ważnym wskaźnikiem, podobnie jakim bioróżnorodność jest aktualnie.

\section{Propozycja badawcza i metodyczna oceny georóżnorodności}

Dokonany przegląd literatury dotyczący koncepcji i rozumienia georóżnorodności, jak również metod jej oceny, pozwala na dalsze poszukiwania metodyki badania georóżnorodności w różnych uwarunkowaniach środowiskowych i skalach przestrzennych. Poszukiwania te są i będą realizowane w ramach długofalowego badania georóżnorodności na zróżnicowanych morfometrycznie, morfologicznie, morfogenetycznie i morfochronologicznie obszarach Polski i Szwajcarii. Główną intencją zaplanowanych badań jest wypracowanie innowacyjnego postępowania badawczego oceny georóżnorodności, przy wykorzystaniu analizy wielokryterialnej MCE (ang. Multi-criteria evaluation) zintegrowanej w systemie geoinformacyjnym, z zastosowaniem hierarchicznej analizy procesów decy- 
zyjnych AHP (ang. Analytic hierarchy process), zaproponowanej przez Saaty'ego (1977, 1980, 1994). Docelowo, jeden algorytm winien $\mathrm{z}$ powodzeniem być stosowany zarówno dla obszarów charakteryzujących się wysoką energią rzeźby jak np. krajobraz gór wysokich, jak i obszarów nizinnych, o potencjalnie niższym i mniejszym zróżnicowaniu środowiska, jak i samej georóżnorodności. Punktem wyjścia planowanych badań jest bowiem hipoteza, mówiąca o tym, iż komponenty środowiska geograficznego w różnym stopniu wpływają na georóżnorodność krajobrazu. Banalność tej hipotezy wydaje się być tylko pozorna, bowiem odpowiedni dobór metod oceny komponentów środowiska oraz przypisanie im wartości w postaci wag, warunkuje poprawność określenia stopnia georóżnorodności dowolnego obszaru, czy to w obrębie teorii zbiorów klasycznych (Kuratowski, Mostowski 1978), czy teorii zbiorów rozmytych (Zadeh 1965).

W celu zobiektywizowania badań oraz wykorzystania metodologicznego podejścia systemowego, przyjęto do delimitacji testowych obszarów badawczych jednostkę przestrzenną, naturalną, jaką jest zlewnia rzeczna. W opinii Kostrzewskiego (1993) oraz Kostrzewskiego i in. (1994, 1995) zlewnię rzeczną można traktować jako geoekosystem, a więc fragment przestrzeni, umożliwiający całościowe ujęcie obiegu energii i materii oraz odznaczający się charakterystyczną strukturą krajobrazową. W niniejszej pracy sformułowano następujące kryteria wyboru zlewni do badań nad ich georóżnorodnością:

- zlewnie zlokalizowane w umiarkowanej strefie klimatycznej, charakterystycznej dla Europy Środkowej,
- zlewnie o podobnej wielkości, lecz zróżnicowanej hipsometrii, genezie, wieku oraz strukturze krajobrazowej,

- zlewnie znajdujące się pod ochroną prawną w celu ograniczenia wpływu działalności człowieka na ich rozwój.

Opierając się na powyższych założeniach wyznaczono cztery górskie zlewnie rzeczne na obszarze Polski (ryc. 1) oraz Szwajcarii (ryc. 2), jako geoekosystemy szczególnie wrażliwe na zmiany środowiska geograficznego i różnicujące się pod wieloma względami przyrodniczymi (tab. 1). Są to kolejno zlewnie Derborence i Illgraben w Alpach Szwajcarskich, Suchej Wody w Tatrach oraz Wrzosówki w Karkonoszach. Ponadto w celach porównawczych wybrano zlewnię rzeczną na nizinnym obszarze młodoglacjalnym (Pomorze Zachodnie), zlewnię Dębnicy (tab. 1), lewobrzeżnego dopływu Parsęty (ryc. 1).

Na rycinie 3 przedstawiony został ogólny schemat pojęciowy procesu oceny georóżnorodności dla dowolnego celu i zakresu opracowania. Znajduje on zastosowanie zarówno w przypadku oceny georóżnorodności kompleksowej wybranego obszaru badań, jak i komponentowej w obrębie poszczególnych sfer powierzchni Ziemi. W założeniu, analiza jest wykonywana w systemach informacji geograficznej, przy użyciu analogowych oraz cyfrowych zasobów geodanych, zintegrowanych na platformie geoinformacyjnej.

Proponowana metodyka oceny georóżnorodności, przetestowana na wspomnianych powyżej zlewniach rzecznych, wpisuje się w schemat ogólny oceny georóżno-

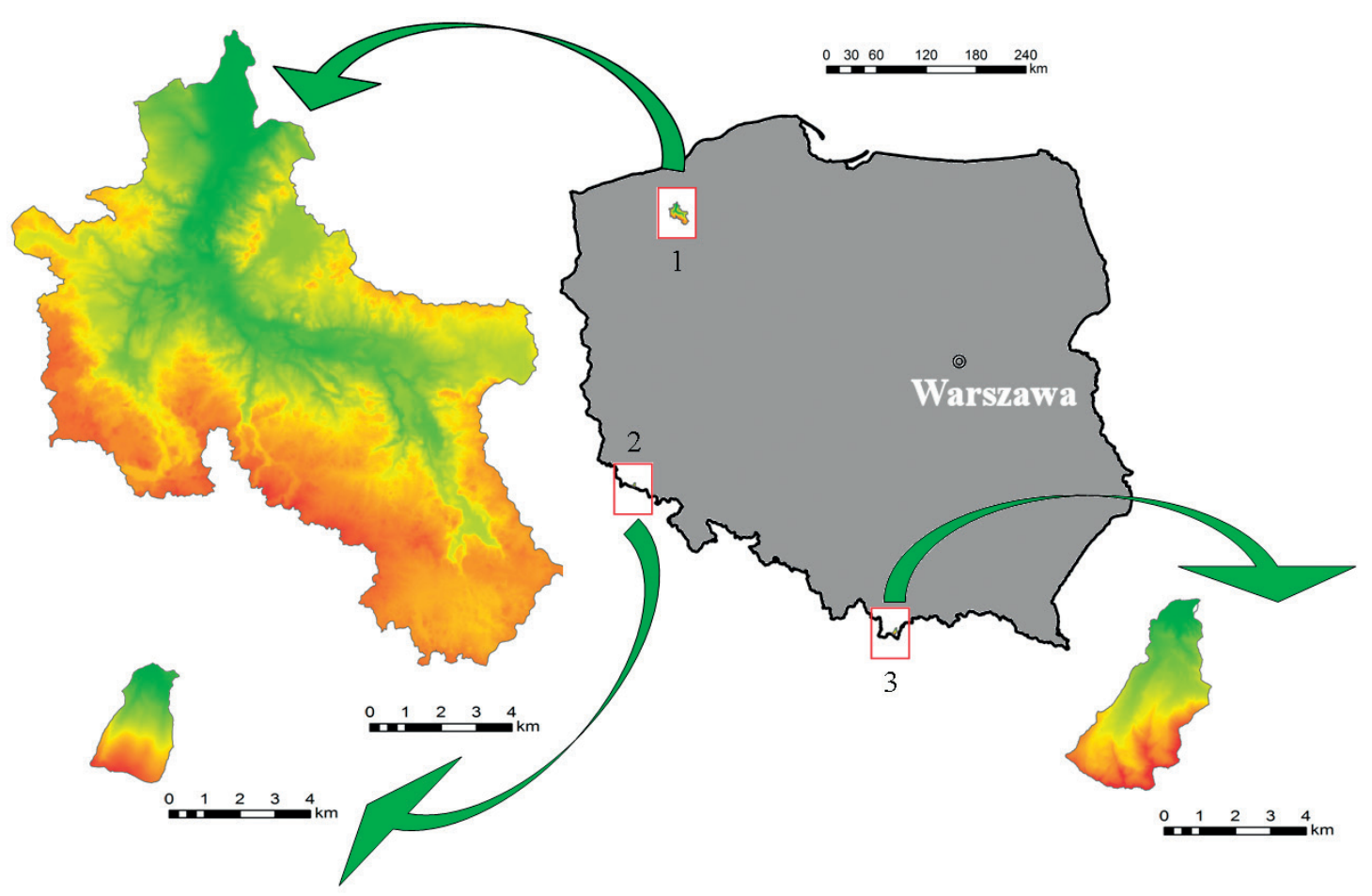

Ryc. 1. Lokalizacja zlewni testowych w Polsce

1 - zlewnia Dębnicy na Pomorzu Zachodnim, 2 - zlewnia Wrzosówki w Karkonoszach, 3 - zlewnia Suchej Wody w Tatrach

Fig. 1. Location of research areas in Poland

1 - Dębnica catchment, West Pomerania, 2 - Wrzosówka catchment, Karkonosze Mts., 3 - Sucha Woda catchment, Tatra Mts 
Tabela.1. Charakterystyki porównawcze wybranych zlewni testowych

Table 1. Comparative characteristics for selected test catchments

\begin{tabular}{|c|c|c|c|c|c|c|}
\hline \multirow{3}{*}{$\begin{array}{l}\text { Parametr } \\
\text { Parameter }\end{array}$} & \multirow{3}{*}{$\begin{array}{l}\text { Jed- } \\
\text { nostka } \\
\text { Unit }\end{array}$} & \multicolumn{5}{|c|}{ Zlewnia testowa / Test catchment } \\
\hline & & Derborence & Illgraben & Sucha Woda & Wrzosówka & Dębnica \\
\hline & & $\begin{array}{c}\text { Alpy Berneńskie } \\
\text { Bernese Alps }\end{array}$ & $\begin{array}{l}\text { Alpy Pennińskie } \\
\text { Pennine Alps }\end{array}$ & $\begin{array}{c}\text { Tatry } \\
\text { Tatra Mountains } \\
\end{array}$ & $\begin{array}{c}\text { Karkonosze } \\
\text { Karkonosze Mountains }\end{array}$ & $\begin{array}{l}\text { Pomorze Zachodnie } \\
\text { Western Pomerania }\end{array}$ \\
\hline \multicolumn{7}{|c|}{ Parametry geomorfometryczne / Geomorphometric parameters } \\
\hline $\begin{array}{l}\text { Powierzchnia } \\
\text { zlewni A } \\
\text { Catchment area } \\
\end{array}$ & {$\left[\mathrm{km}^{2}\right]$} & 60,4 & 18,5 & 24,8 & 11,5 & 289,1 \\
\hline $\begin{array}{l}\text { Obwód zlewni P } \\
\text { Catchment peri- } \\
\text { meter }\end{array}$ & {$[\mathrm{km}]$} & 39,4 & 25,1 & 26,8 & 15,3 & 127,5 \\
\hline $\begin{array}{l}\text { Średni spadek } \\
\text { zlewni } \mathrm{R} \\
\text { Average catch- } \\
\text { ment slope }\end{array}$ & {$\left[{ }^{\circ}\right]$} & 26,7 & 24,6 & 21,8 & 13,9 & 2,9 \\
\hline \multicolumn{7}{|c|}{ Charakterystyki hipsometryczne / Hypsometric characteristics } \\
\hline $\begin{array}{l}\text { Wysokość maksy- } \\
\text { malna zlewni } \mathrm{H}_{\max } \\
\text { Maximum altitude }\end{array}$ & $\begin{array}{c}{[\mathrm{m}} \\
\text { n.p.m. }]\end{array}$ & 3206,5 & 2784,6 & 2301 & 1421,8 & 221,6 \\
\hline $\begin{array}{l}\text { Wysokość mini- } \\
\text { malna zlewni } \mathrm{H}_{\min } \\
\text { Minimum altitude }\end{array}$ & $\begin{array}{c}{[\mathrm{m}} \\
\text { n.p.m. }]\end{array}$ & 472,9 & 560,5 & 908,2 & 531,2 & 41,5 \\
\hline $\begin{array}{l}\text { Średnia wysokość } \\
\text { zlewni } \mathrm{H}_{\text {sr. }} \\
\text { Mean catchment } \\
\text { altitude }\end{array}$ & $\begin{array}{c}{[\mathrm{m}} \\
\text { n.p.m. }]\end{array}$ & 1756,5 & 1361,6 & 1517,9 & 948,9 & 129,4 \\
\hline \multicolumn{7}{|c|}{ Cechy hydrograficzne / Hydrographic parameters } \\
\hline $\begin{array}{l}\text { Długość cieku } \\
\text { głównego L } \\
\text { Stream length }\end{array}$ & {$[\mathrm{km}]$} & 11,6 & 5,5 & 15,5 & 5,4 & 39,6 \\
\hline $\begin{array}{l}\text { Średni spadek } \\
\text { rzeki głównej S } \\
\text { Mean stream slope }\end{array}$ & {$\left[{ }^{\circ}\right]$} & 20,1 & 17,4 & 6,9 & 15,7 & 0,8 \\
\hline $\begin{array}{l}\text { Wskaźnik jezior- } \\
\text { ności } \mathrm{J}_{0} \\
\text { Lake density }\end{array}$ & {$[\%]$} & 0,2 & 1,2 & 1,3 & 0,0 & 1,2 \\
\hline \multicolumn{7}{|c|}{ Charakterystyki środowiskowe / Environmental characteristics } \\
\hline $\begin{array}{l}\text { Geologia/litologia } \\
\text { Geology/lithology }\end{array}$ & {$[-]$} & $\begin{array}{c}\text { wapienie, } \\
\text { dolomity i } \\
\text { piaskowce, flisz, } \\
\text { czwartorzędowe } \\
\text { pokrywy more- } \\
\text { nowe limestones, } \\
\text { dolomites and } \\
\text { sandstones, } \\
\text { flysch, Quaterna- } \\
\text { ry moraine cover }\end{array}$ & $\begin{array}{l}\text { utwory czwarto- } \\
\text { rzędowe, gips i } \\
\text { kwarcyty, dolo- } \\
\text { mity i wapienie } \\
\text { Quaternary de- } \\
\text { posits, gypsum } \\
\text { and quartzites, } \\
\text { dolomites and } \\
\text { limestones }\end{array}$ & $\begin{array}{l}\text { granitoidy, skały } \\
\text { metamorficzne, } \\
\text { dolomity i wapienie } \\
\text { triasowe, utwory } \\
\text { czwartorzędowe } \\
\text { granitoids, me- } \\
\text { tamorphic rocks, } \\
\text { Triassic dolomites } \\
\text { and limestones, Qu- } \\
\text { aternary deposits }\end{array}$ & $\begin{array}{l}\text { granity porfirowate i } \\
\text { równoziarniste, utwo- } \\
\text { ry czwartorzędowe } \\
\text { porphyry and equ- } \\
\text { igranular granite, } \\
\text { Quaternary deposits }\end{array}$ & $\begin{array}{l}\text { czwartorzędowe } \\
\text { gliny morenowe, } \\
\text { piaski i żwiry flu- } \\
\text { wioglacjalne } \\
\text { Quaternary mo- } \\
\text { raine tills, fluvio- } \\
\text { glacial sands and } \\
\text { gravels }\end{array}$ \\
\hline $\begin{array}{l}\text { Geomorfologia } \\
\text { Geomorphology }\end{array}$ & {$[-]$} & $\begin{array}{l}\text { dolina postgla- } \\
\text { cjalna } \\
\text { postglacial } \\
\text { valley }\end{array}$ & $\begin{array}{l}\text { dolina toren- } \\
\text { cyjna } \\
\text { torrential valley }\end{array}$ & $\begin{array}{c}\text { dolina postgla- } \\
\text { cjalna } \\
\text { postglacial valley }\end{array}$ & $\begin{array}{l}\text { dolina postglacjalna } \\
\text { postglacial valley }\end{array}$ & $\begin{array}{c}\text { dolina rozcinająca } \\
\text { wysoczyznę more- } \\
\text { nową } \\
\text { moraine upland } \\
\text { valley }\end{array}$ \\
\hline $\begin{array}{l}\text { Pokrycie terenu } \\
\text { Land cover }\end{array}$ & {$[-]$} & $\begin{array}{l}\text { odsłonięte skały, } \\
\text { lasy miesza- } \\
\text { ne, murawy } \\
\text { i pastwiska } \\
\text { naturalne } \\
\text { bare rocks, } \\
\text { mixed forest, na- } \\
\text { tural grasslands }\end{array}$ & $\begin{array}{l}\text { lasy iglaste, } \\
\text { odsłonięte } \\
\text { skały, zabudowa } \\
\text { miejska luźna } \\
\text { coniferous fo- } \\
\text { rest, bare rocks, } \\
\text { discontinous } \\
\text { urban fabric }\end{array}$ & $\begin{array}{c}\text { lasy iglaste, wrzo- } \\
\text { sowiska i zakrza- } \\
\text { czenia (kosodrze- } \\
\text { wina), odsłonięte } \\
\text { skały } \\
\text { coniferous forest, } \\
\text { moors and heath- } \\
\text { land, bare rocks }\end{array}$ & $\begin{array}{c}\text { lasy iglaste, lasy i } \\
\text { roślinność krzewiasta } \\
\text { w stanie zmian, lasy } \\
\text { liściaste } \\
\text { coniferous forest, } \\
\text { transitional wo- } \\
\text { odland-shrub, decidu- } \\
\text { ous forest }\end{array}$ & $\begin{array}{l}\text { grunty orne, lasy } \\
\text { iglaste, lasy liściaste } \\
\text { arable land, } \\
\text { coniferous forest, } \\
\text { deciduous forest }\end{array}$ \\
\hline
\end{tabular}




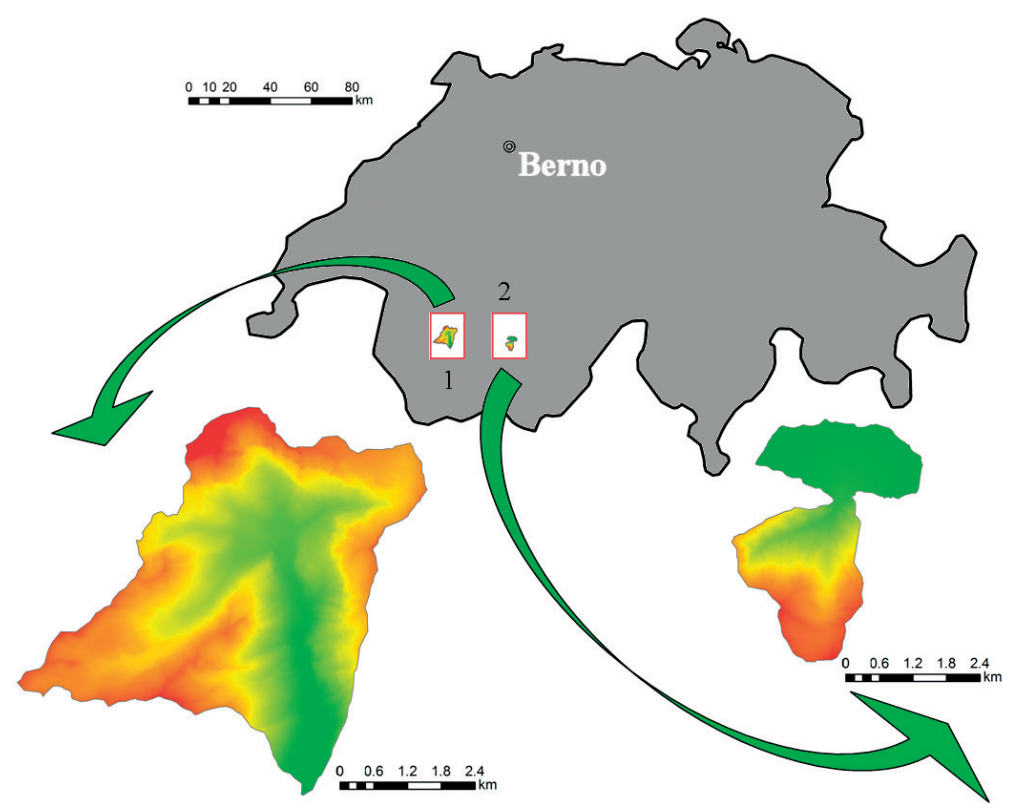

Ryc. 2. Lokalizacja zlewni testowych w dorzeczu Rodanu w Szwajcarii

1 - zlewnia Derborence, 2 - zlewnia Illgraben

Fig. 2. Location of research areas in the Rhone River basin in Switzerland

1 - Derborence catchment, 2 - Illgraben catchment

rodności. Pierwszym krokiem, po określeniu celu i zakresu opracowania, a zarazem najbardziej pracochłonnym, jest pozyskanie i integracja geodanych dla obszaru badań. Podstawą algorytmu analitycznego jest odpowiedni dobór kryteriów oceny, a więc takich cech środowiska geograficznego (komponentów środowiska przyrodniczego jak np.: budowa geologiczna/litologia, gleby, hydrografia i parametrów geomorfometrycznych takich jak: energia rzeźby, topograficzny wskaźnik wilgotności, krzywizny, itp.), w nawiązaniu do definicji georóżnorodności (Gray 2004, 2013), które z jednej strony w sposób najpełniejszy charakteryzują georóżnorodność terenu, a z drugiej strony - dają szansę na wskazanie różnic morfometrycznych i morfologicznych rzeźby obszarów testowych. Po obliczeniu poszczególnych miar komponentów środowiska przyrodniczego i parametrów geomorfometrycznych, czynnością obciążoną pewną dozą subiektywizmu, jest ich ocena $\mathrm{z}$ punktu widzenia potencjalnego wpływu na georóżnorodność obszarów badawczych. Innymi słowy, przeprowadzana jest bonitacja jakościowa z wykorzystaniem systemu eksperckiego oraz bonitacja ilościowa z wykorzystaniem metod klasyfikacji, a następnie reklasyfikacji danych do 5 klas georóżnorodności. W efekcie otrzymywane są mapy czynnikowe (mapy ocen cząstkowych). Następnie wybierany jest wariant analizy wielokryterialnej z wykorzystaniem analizy procesów decyzyjnych (ang. Analytic hierarchy process). W nawiązaniu do postawionej hipotezy, istotność map czynnikowych w procesie decyzyjnym jest różna. Kluczową więc czynnością wykonania mapy georóżnorodności, jest wyliczenie odpowiednio dobranych wag dla poszczególnych map ocen cząstkowych. Dokonywane jest to przy wykorzystaniu metody porównania parami Saaty'ego (1977, 1980, 1994). Ostatnim krokiem postępowania badawczego, po wygenerowaniu wynikowej, szczegółowej mapy georóżnorodności jest jej reklasyfikacja do 5 klas wartości georóżnorodności: bardzo małej, małej, średniej, dużej i bardzo dużej. Na rycinie 4 przedstawione zostały dwie przykładowe mapy georóżnorodności kompleksowej, o skrajnie różnych cechach krajobrazu: zlewnia górska Derborence, w Alpach Szwajcarskich oraz nizinna - Dębnica, na Pomorzu Zachodnim.

\section{Konkluzja końcowa}

Przegląd literatury polskiej i zagranicznej dotyczącej georóżnorodności, a szczególnie metod jej oceny wskazuje, że problematyka ta jest nader skromnie rozwinięta. O ile podejście metodologiczne georóżnorodności można uznać, że jest w miarę dobrze rozpracowane, to o tyle metody badań georóżnorodności pozostawiają wiele niejasności. Głównym mankamentem jest brak jednoznacznie wypracowanego schematu postępowania badawczego oraz wskazania kryteriów oceny przy rozpoznawaniu georóżnorodności dowolnego obszaru. Brak obiektywnego podejścia badawczego georóżnorodności powoduje, że wiele opisywanych jej przykładów nie można poddać studiom porównawczym. Zróżnicowane założenia, kryteria, miary georóżnorodności są przyczyną nieporównywalności stosowanych metod i ocen zarówno georóżnorodności kompleksowej jak i komponentowej. Stąd w niniejszym artykule podjęto próbę wskazania zmierzającej w kierunku uniwersalizmu i obiektywizmu metody oceny georóżnorodności poprzez analizę geoinformacyjną. Metoda ta jest testowana na obszarach o wyraźnych cechach georóżnorodności, tj. obszarach wysokogórskich (zlewnie Derborence i Illgraben w Alpach oraz Wrzosówki w Kar- 


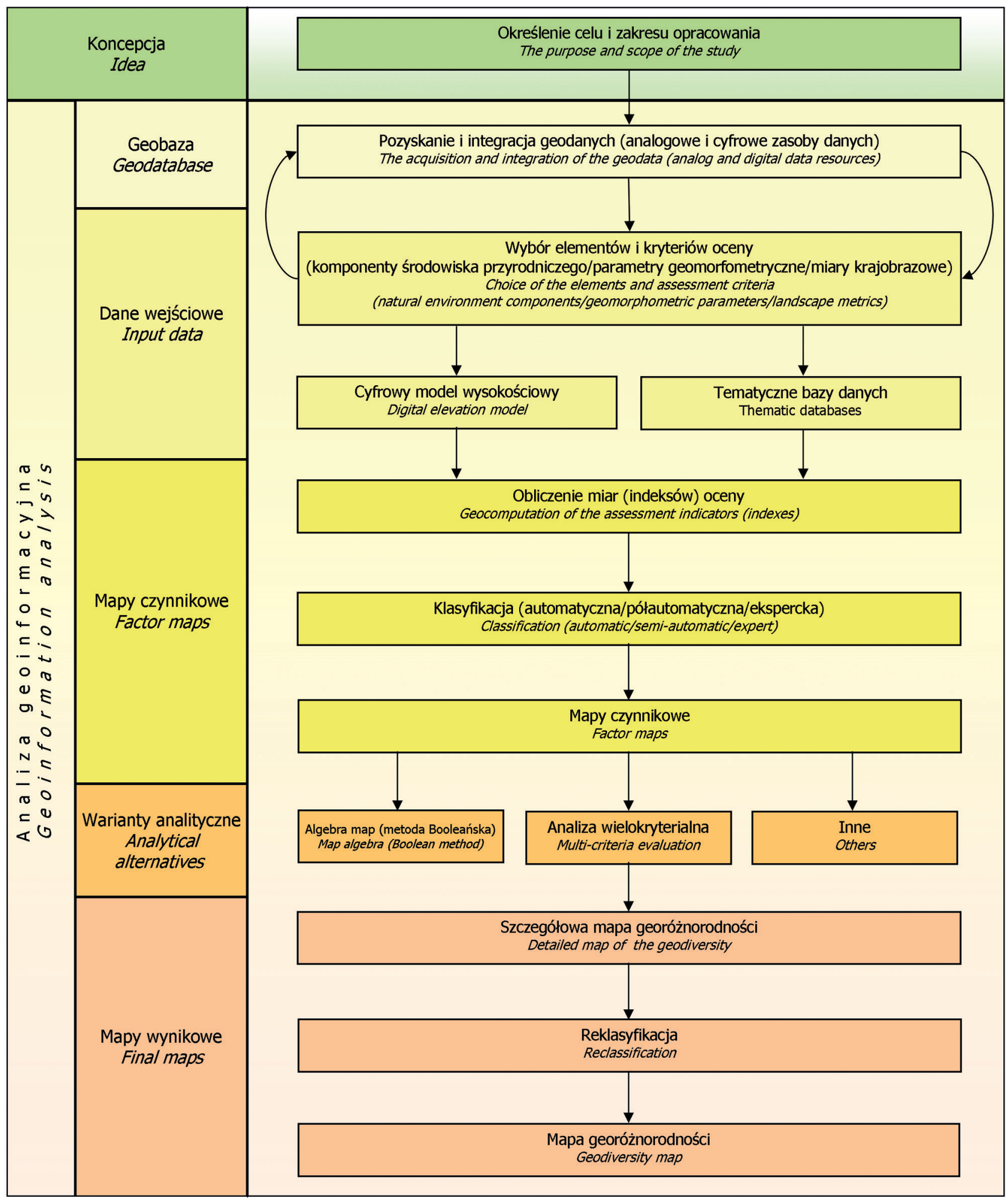

Ryc. 3. Ogólny schemat postępowania badawczego oceny georóżnorodności w systemach geoinformacyjnych Fig. 3. General research workflow of geodiversity assessment in the geoinformation systems

konoszach i Suchej Wody w Tatrach), a jej przydatność jest weryfikowana na obszarze nizinnym o zdecydowanie mniejszym stopniu georóżnorodności (zlewnia Dębnicy na Pomorzu). Zamierzeniem tych badań jest ustanowienie standardów metodologicznych i metodycznych właściwego rozpoznania georóżnorodności dowolnego obszaru na kuli ziemskiej.
Przeprowadzone badania i analizy oraz dotychczas zaprezentowane wstępne wyniki na międzynarodowych konferencjach (Jaskulska i in. 2013, Najwer, Zwoliński 2014, 2015, Najwer i in. 2014, Mazurek i in. 2015) potwierdziły słuszność przyjętych założeń metodologicznych i metodycznych podjętego problemu oceny georóżnorodności. W toku postępowania badawczego zwrócono 

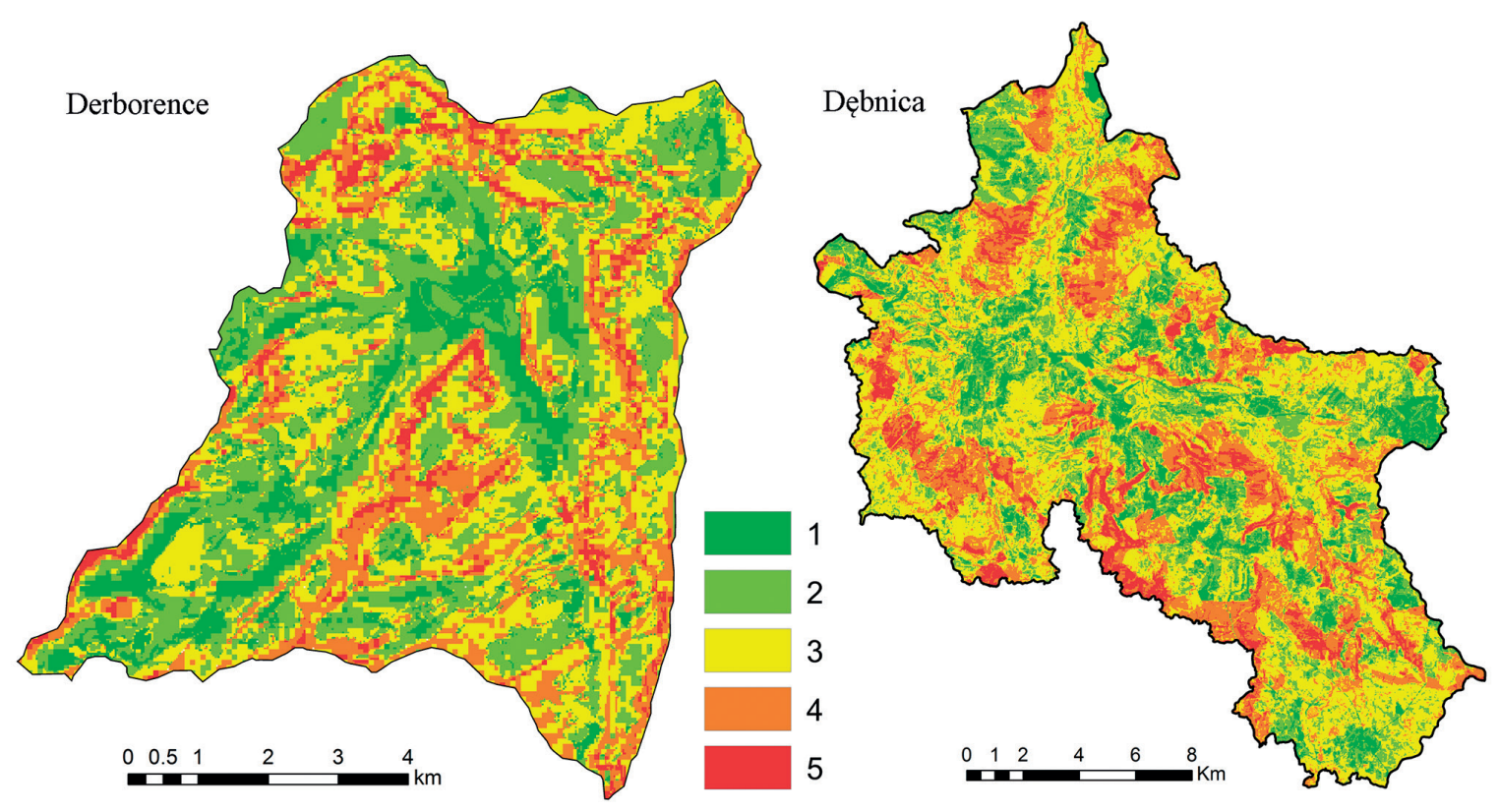

Ryc. 4. Mapy georóżnorodności: zlewni górskiej - Derborence oraz zlewni nizinnej - Dębnicy

Klasy georóżnorodności: 1 - bardzo mała, 2 - mała, 3 -średnia, 4 - duża i 5 - bardzo duża

Fig. 4. Geodiversity maps: mountainious catchment - Derborence and lowland catchment - Dębnica

Geodiversity values: 1 - very low, 2 - low, 3 - medium, 4 - high, 5 - very high

uwagę, iż na poprawność otrzymywanych map czynnikowych i wynikowych, znaczący wpływ mają głównie dwa aspekty tych analiz, a mianowicie: jakość danych źródłowych, głównie ich dokładność oraz wielkość gridu oceny głównie rozumiana jako rozdzielczość geodanych. Dlatego też, już na wstępie do badań bardziej szczegółowych można zaznaczyć, iż niezwykle istotne jest ustalenie pewnych wytycznych oceny georóżnorodności, w zależności od docelowej skali przestrzennej opracowań.

W idei, propozycja metodyczna, która została wypracowana $\mathrm{i}$ wstępnie przedstawiona w ogólnych zarysach, ma znaleźć wykorzystanie nie tylko w ramach prac związanych z Grupą Roboczą Oceny Georóżnorodności Rzeźby (ang. Working Group on Landform Assessment for Geodiversity), która została powołana w 2013 roku w ramach IAG (ang. International Association of Geomorphologists), ale również w szeroko pojętych analizach krajobrazowych oraz w dalszych pracach nad relacjami miedzy georóżnorodnością i bioróżnorodnością a zachowaniem dziedzictwa przyrodniczego i kulturowego.

\section{Podziękowania}

Alicja Najwer składa podziękowanie prof. Emmanuelowi Reynardowi z Departamentu Geografii na Uniwersytecie w Lozannie za możliwość odbycia stażu, udostępnienie danych dla zlewni alpejskich oraz ogromne wsparcie naukowe i bezcenne wskazówki podczas stażu. Autorzy są wdzięczni prof. E. Reynardowi za wspólne prace terenowe oraz liczne konsultacje. Autorzy dziękują Tatrzańskiemu Parkowi Narodowemu oraz Karkonoskiemu Parkowi Narodowemu za udostępnienie danych o środowisku przyrodniczym zlewni Suchej Wody i Wrzosówki, a także za pozwolenia na prowadzenie prac badawczych na terenie tych zlewni. Autorzy składają podziękowanie trzem anonimowym recenzentom za uwagi i komentarze, które udoskonaliły pierwotną wersję artykułu.

\section{Udzial autorów}

Alicja Najwer jest odpowiedzialna za koncepcję i napisanie artykułu, zebranie, analizę i interpretację danych, wykonanie dokumentacji graficznej. Zbigniew Zwoliński jest odpowiedzialny za koncepcję artykułu, krytyczne przejrzenie artykułu i ostateczną aprobatę artykułu do opublikowania. Autorzy dzielą się wkładem procentowym następująco: Alicja Najwer - 75\%, Zbigniew Zwoliński - 25\%.

\section{Literatura}

Alexandrowicz Z., 2003. Ochrona dziedzictwa geologicznego Polski w koncepcji europejskiej sieci geostanowisk. Przegląd Geologiczny 51(3): 224-230.

Alexandrowicz Z., 2004. Perspektywy rozwoju geoochrony w krajach Wspólnoty Europejskiej. Chrońmy Przyrodę Ojczystą 60: 87-99.

Alexandrowicz Z., 2006. Framework of European geosites in Poland. Nature Conservation 62(5): 63-87.

Alexandrowicz Z., 2007. Geoochrona w ujęciu narodowym, europejskim i światowym (ze szczególnym uwzględnieniem Polski). Biuletyn PIG 425: 19-26.

Alexandrowicz Z., Margielewski W., 2010. Impact of mass movements on geo-and biodiversity in the Polish Outer (Flysch) Carpathians. Geomorphology 123: 290-304.

Alexandrowicz Z., Poprawa D., 2000. Ochrona georóżnorodności w polskich Karpatach z Mapą chronionych i proponowanych do ochrony obszarów i obiektów przyrody nieożywionej 1:400 000. Min. Środ. i Państ. Inst. Geol., Warszawa.

Australian Heritage Commission, 1996. Australian Natural Heritage Charter. 1st ed. Canberra. 
Australian Heritage Commission, 2002. Australian Natural Heritage Charter for the Conservation of Places of Natural Heritage Significance. Australian Heritage Commission in association with Australian Committee for IUCN. Sydney.

Barthlott W., Biedinger N., Braun G., Feig F., Kier G., Mutke J., 1999. Terminological and methodological aspects of the mapping and analysis of the global biodiversity. Acta Botanica Fennica 162: 103-110.

Bartkowski T., 1977. Metody badań geografii fizycznej. Państwowe Wydawnictwo Naukowe. Warszawa-Poznań.

Benito-Calvo A., Pe'rez-Gonza'lez A., Magri O., Meza P., 2009. Assessing regional geodiversity: the Iberian Peninsula. Earth Surface Process \& Landforms 34(10): 1433-1445.

Burek C., Potter J., 2006. Local Geodiversity Action Plans - Setting the Context for Geological Conservation. W: J.Larwood (red.), English Nature Research Report 560. Peterborough.

Bródka S., 2010. Etapy oceny środowiska przyrodniczego w ujęciu praktycznym. W: S. Bródka (red.), Praktyczne aspekty ocen środowiska przyrodniczego. Bogucki Wydawnictwo Naukowe. Poznań.

Burnett M.R., August P.V., Brown J.H., Killingbeck K.T., 1998. The influence of geomorphological heterogeneity on biodiversity. I. A patch-scale perspective. Conservation Biology 12(2): 363-370.

Comanescu L., Nedelea A., 2012. The assessment of geodiversity a premise for declaring the geopark Buzaului County (Romania). Journal of Earth System Science 121(6): 1493-1500.

Degórski M., 2001. Pedosfera - komponent środowiska łączący abiotyczną i biotyczną różnorodność. W: E.Roo-Zielińska, J.Solon (red.), Między geografią i biologią - badania nad przemianami środowiska przyrodniczego. Prace Geograficzne IG i PZ PAN 179: 227-238.

Dixon G., 1996. Geoconservation: An International Review and Strategy for Tasmania. Occasional Paper 35, Parks \& Wildlife Service, Tasmania.

Duff K., 1994. Natural Areas: an holistic approach to conservation based on geology. Geological and Landscape Conservation: 121-126. London.

Eberhard R., 1997. Pattern \& Process: Towards a Regional Approach to National Estate Assessment of Geodiversity. Australian Heritage Commission, Canberra.

Gawlikowska E., 2000. Ochrona georóżnorodności na Dalnym Śląsku z Mapa chronionych obszarów i obiektów przyrody nieożywionej 1:300 000. Min. Środ. i Państ. Inst. Geol., Warszawa.

Gonera M., 2005. Zabytki przyrody nieożywionej, czyli dobro nie powszechnego użytku. Przegląd Geologiczny 53(3): 199-204.

Gonera M., 2008. Geoochrona konserwatorska w realiach rzeczywistości rynkowej. Chrońmy Przyrodę Ojczystą 64(5): 127-142.

Gordon J.E., 2012. Engaging with Geodiversity: 'Stone Voices', Creativity and Ecosystem Cultural Services in Scotland. Scottish Geographical Journal 128: (3-4).

Gordon J.E., Barron H.F., 2011. Scotland's geodiversity: development of the basis for a national framework. Scottish Natural Heritage. Scottish Natural Heritage Commissioned Report No. 417.

Gordon J.E., Barron H. F., 2013. The role of geodiversity in delivering ecosystem services and benefits in Scotland. Scottish Journal of Geology 49(1): 41-58.

Gordon J.E., Barron H.F., Hansom J.D., Thomas M.F., 2012. Engaging with geodiversity - why it matters. Proceedings of the Geologists' Association 123: 1-6.

Gordon J.E., Dvorak I., Jonasson C., Josefsson M., Kocianova M., Thompson D.B.A., 2002. Geo-ecology and management of sensitive montane landscapes. Geografiska Annaler 84 A: 193-203.

Gray M., 2004. Geodiversity: Valuing and Conserving Abiotic Nature. John Wiley and Sons, Chichester.

Gray M., 2008. Geodiversity: The origin and evolution of a paradigm. W: C.V.Burek, C.D.Prosser (red.), The History of Geoconservation, Geological Society of London. Special Publication 300: 31-36.

Gray M., 2013. Geodiversity: Valuing and Conserving Abiotic Nature. 2nd Edition. John Wiley and Sons, Chichester.

Gray M., Gordon J.E., Brown E.J., 2013. Geodiversity and the ecosystem approach: the contribution of geoscience in delivering integrated environmental management. Proceedings of the Geologists' Association 124(4): 659-673.
Hjort J., Heikkinen K., Luoto M., 2012. Inclusion of explicit measures of geodiversity improve biodiversity models in a boreal landscape. Biodiversity Conservation 21: 3487-3506.

Hjort J., Luoto M., 2010. Geodiversity of high-latitude landscapes in northern Finland. Geomorphology 115(1-2): 109-116.

Hjort J., Luoto M., 2012. Can geodiversity be predicted from space? Geomorphology 153-154: 74-80.

Ibáñez J.J., Krasilikov P.V., Saldaña A., 2012. Archive and refugia of soil organisms: applying a pedodiversity framework for the conservation of biological and nonbiological heritages. Journal of Applied Ecolology 49: 1267-1277.

IPCC, 2007. Zmiana klimatu 2007. Raport Syntetyczny. Pachauri R.K., Reisinger A. (red.), Wkład Grup roboczych I, II i III do Czwartego Raportu Oceniającego Międzynarodowego Zespołu ds. Zmian Klimatu,Wyd. IOŚ, Warszawa.

Jačková K., Romportl D., 2008. The relationship between geodiversity and habitat richness in Šumava. National Park and Křivoklátsko Pla (Czech Republic): a quantitative analysis approach. Journal of Landscape Ecology 1: 23-38.

Jania J., Zwoliński Zb., 2011. Ekstremalne zdarzenia meteorologiczne, hydrologiczne i geomorfologiczne w Polsce. Landform Analysis 15: 51-64.

Jaskulska A., Reynard E., Zwolinski Zb., 2013. Geodiversity assessment for environmental management of geomorphosites: Derborence and Illgraben, Swiss Alps. EGU General Assembly Conference Abstracts 15: 838 .

Jedicke E., 2001. Biodiversität, Geodiversität, Ökodiversität. Kriterien zur Analyse der Landschaftsstruktur - ein konzeptioneller Diskussionsbeitrag. Naturschutz und Landschaftsplanung 33(2/3): 59-68.

Kiernan K., 1995. An Atlas of Tasmanian Karst, 2 vols, Report 10 (2 vols), Tasmanian Forest Research Council, Hobart.

Kiernan K. 1996. The Conservation of Glacial Landforms. Hobart, Tasmania: Forest Practices Unit.

Kistowski M., 2012. Prawne możliwości ochrony georóżnorodności i różnorodności krajobrazowej w warunkach polskich. Annales UMCS LXVII (2): 45-62.

Kostrzewski A., 1993. Zintegrowany Monitoring Środowiska Przyrodniczego w Polsce. W: A. Kostrzewski (red.), Biblioteka Monitoringu Środowiska, Warszawa.

Kostrzewski A., 1998. Georóżnorodność rzeźby jako przedmiot badań geomorfologii. W: K.Pękala (red.), Główne kierunki badań geomorfologicznych w Polsce, IV Zjazd Geomorfologów Polskich. UMCS, Lublin, 11-16.

Kostrzewski A., 2011. The role of relief geodiversity in geomorphology. Geographia Polonica 84, Special Issue Part 2: 69-74.

Kostrzewski A., Kozacki L., Zwoliński Zb., 1997a. Georóżnorodność krajobrazu. Arch. Państ. Inst. Geol., Warszawa.

Kostrzewski A., Kozacki L., Zwoliński Zb., 1998a. Georóżnorodność krajobrazu. Arch. Państ. Inst. Geol., Warszawa.

Kostrzewski A., Mazurek M., Stach A., 1995. Zintegrowany monitoring środowiska przyrodniczego: zasady organizacji, system pomiarowy, wybrane metody badań. PIOŚ, Warszawa.

Kostrzewski, A., Mazurek, M., Zwoliński, Zb., 1994. Dynamika transportu fluwialnego górnej Parsęty jako odbicie funkcjonowania systemu zlewni. Stowarzyszenie Geomorfologów Polskich, Poznań.

Kostrzewski A., Starkel L., Zwoliński Zb., 1997b. Georóżnorodność rzeźby. Arch. Państ. Inst. Geol., Warszawa.

Kostrzewski A., Starkel L., Zwoliński Zb., 1998b. Georóżnorodność rzeźby. Arch. Państ. Inst. Geol., Warszawa.

Kot R., 2005a. Georóżnorodność fordońskiego odcinka doliny dolnej Wisły i jej otoczenia na przykładzie oceny budowy geologicznej i gleb. Acta Universitatis Nicolai Copernici Geografia 33: 105-128.

Kot R., 2005b. Ocena georóżnorodności klimatu na przykładzie fordońskiego odcinka doliny dolnej Wisły i jej otoczenia w skali 1:25 000. W: A.Szponar, S.Horska-Schwarz (red.), Struktura przestrzenno-funkcjonalna krajobrazu, Problemy Ekologii Krajobrazu 17: 257-271.

Kot R., 2005c. Ocena georóżnorodności rzeźby terenu na przykładzie fordońskiego odcinka doliny dolnej Wisły i jej otoczenia w skali 1:25000. W: A.Kostrzewski, R.Kolander (red.), Funkcjonowanie geoekosystemów Polski w warunkach zmian klimatu i różnokierun- 
kowej antropopresji, Biblioteka Monitoringu Środowiska, Poznań, 475-484.

Kot R., 2006a. Georóżnorodność - problem jej oceny i zastosowania w ochronie i kształtowaniu środowiska na przykładzie fordońskiego odcinka Doliny Dolnej Wisły i jej otoczenia. Towarzystwo Naukowe w Toruniu, UMK, Toruń.

Kot R., 2006b. Ocena georóżnorodności wód na przykładzie fordońskiego odcinka doliny dolnej Wisły i jej otoczenia w skali 1: 25000. W: R.J.Klimko (red.), Restrukturyzacja i projektowanie systemów terytorialno-krajobrazowych, Problemy Ekologii Krajobrazu 15: 115-124.

Kot R. 2012. Zastosowanie indeksu georóżnorodności dla określenia zróżnicowania rzeźby terenu na przykładzie zlewni reprezentatywnej Strugi Toruńskiej, Pojezierze Chełmińskie. Problemy Ekologii Krajobrazu 33: 87-96.

Kot R. 2014. The Point Bonitation Method for Evaluating Geodiversity: A Guide with Examples (Polish Lowland). Geografiska Annaler: Series A, Physical Geography 97(2): opublikowane online.

Kot R., Leśniak K., 2006. Ocena georóżnorodności za pomocą miar krajobrazowych - podstawowe trudności metodyczne. Przegląd Geograficzny 78(1): 25-45.

Kot R., Szmidt K., 2010. Ocena georóżnorodności rzeźby terenu fragmentu Basenu Świeckiego w skalach 1:10 000 oraz 1:25 000. Problemy Ekologii Krajobrazu 27: 189-196.

Kozłowski S., 1997. Prognoza ochrony georóżnorodności w Polsce. Przegląd Geologiczny 45(5): 489-496.

Kozłowski S., Migaszewski M.Z., Gałuszka A., 2004. Geodiversity conservation - conserving our geological heritage. Polish Geological Institute Special Papers 13: 13-20.

Krasilnikov P.V., Garcia-Calderon N.E., Ibañez, A., 2009. Pedodiversity in mountainous tropical semideciduous forests of Sierra Madre Del Sur, Mexico. Eurasian Soil Science 42(13): 1435-1442.

Kuratowski K., Mostowski A., 1978. Teoria mnogości. PWN, Warszawa.

Leser H., 1997. Von der Biodiversität zur Landschaftsdiversität. Das Ende des disziplinären Ansatzes der Diversitätsproblematik. W: K.-H.Erdmann (red.), Internationaler Naturschutz, Springer, Berlin Heidelberg New York, 145-175.

Macias A., Bródka S., 2014. Przyrodnicze podstawy gospodarowania przesrzenią. PWN, Warszawa.

Malinowska E., Szumacher I., 2013. Aplication of landscape metrics in the evaluation of geodiversity. Miscellanea Geographica - Regional Studies on Development 17(4): 28-33.

Mazurek M., Najwer A., Borysiak J., Gudowicz J., Zwoliński Zb., 2015. From geodiversity and biodiversity through geoheritage to geoconservation; case study for the Dębnica River drainage basin (Poland). EGU General Assembly 2015 Conference Abstracts 17: 7870.

Melelli L., 2014. Geodiversity: a new quantitative index for natural protected areas enhancement. GeoJournal of Tourism and Geosites 1(13): 27-37.

Migoń P., 2012. Geoturystyka. PWN, Warszawa.

Mihalasky M. J., Bonham-Carter G. F., 2001. Lithodiversity and its spatial association with metallic mineral sites, Great Basin of Nevada. Natural Resources Research 10: 209-226.

Miśkiewicz K., 2009. Problemy badawcze georóżnorodności w geoturystyce, Geoturystyka 1-2: 3-12.

Mizgajski A., 2001. Odniesienie georóżnorodności do wybranych pojęć w naukach o środowisku. W: A.Karczewski, Zb.Zwoliński (red.), Funkcjonowanie geoekosystemów w zróżnicowanych warunkach morfoklimatycznych. Monitoring, ochrona, edukacja. Bogucki Wydawnictwo Naukowe, Poznań, 369-375.

Najwer A., Reynard E., Zwoliński Zb., 2014. GIS and Multi-criteria evaluation (MCE) for landform geodiversity assessment. EGU General Assembly 2014 Conference Abstracts 16: 906.

Najwer A., Zwoliński Zb., 2014. The landform geodiversity assessment method - a comparative analysis for Polish and Swiss mountainous landscape. IGU 2014 Book of Abstracts: 1201.

Najwer A., Zwoliński Zb., 2015. Geomorphometry-based method of landform assessment for geodiversity. EGU General Assembly 2015 Conference Abstracts 17: 980.

Nichols F., Killingbeck K.T., August P.V., 1998. The influence of Geomorphological Heterogeneity on Biodiversity. Conservation Biology 12(2): 371-379.
Panizza M., 2009. The geomorphodiversity of the Dolomites (Italy): a key of geoheritage assessment. Geoheritage 1: 33-42.

Panizza M., 2011. The Dolomites and their geomorphodiversity. Geographia Polonica, 84. Special Issue Part 2: 107-115.

Parks K.E., Mulligan M., 2010. On the relationship between a resource based measure of geodiversity and broad scale biodiversity patterns. Biodiversity and Conservation 19(9): 2751-2766.

Pellitero R., González-Amuchastegui M.J., Ruiz-Flaño P., Serrano E., 2010. Geodiversity and Geomorphosite Assessment Applied to a Natural Protected Area: the Ebro and Rudron Gorges Natural Park (Spain). Geoheritage 3: 163-174.

Pellitero R., Manosso F.C., Serrano E., 2014. Mid- and large-scale geodiversity calculation in Fuentes Carrionas (NW Spain) and Serra do Cadeado (Paraná, Brazil): methodology and application for land management. Geografiska Annaler Series A-Physical Geography. DOI: 10.1111/geoa.12057.

Pereira P., Pereira D.I., Alves M.I.C., 2007. Geomorphosite assessment in Montesinho Natural Park (Portugal). Geographica Helvatica 62(3): 159-168.

Pereira D., Pereira P., Brilha J., Santos L., 2013. Geodiversity assessment of Paraná State (Brazil): an innovative approach. Environmental Management 52: 541-552.

PGI [Państwowy Instytut Geologiczny - Państwowy Instytut], 2011. Georóżnorodność i atrakcje geoturystyczne województwa małopolskiego. Geoturystyczny przewodnik turystyczny, skala: 1:200000 1:10000. Wyd. Compass.

PGI [Państwowy Instytut Geologiczny - Państwowy Instytut Badawczy], 2014. Centralny Rejestr Geostanowisk Polski. Online: http:// geostanowiska.pgi.gov.pl/gsapp/, accessed 20.08.2014.

Prosser C., 2002. Terms of endearment. Earth heritage 17: 13-14.

Prosser C.D., Burek C.V., Evans D.H., Gordon J.E., Kirkbride V., Rennie A.F., Walmsley C.A., 2010. Conserving geodiversity sites in a changing climate: management challenges and responses. Geoheritage 2: 123-136.

Radwanek-Bąk B., Laskowicz I., 2012. Ocena georóżnorodności jako metoda określania potencjału geoturystycznego obszaru. Annales Universitatis Mariae Curie-Skłodowska LXVII(2): 77-95.

Reynard E., Fontana G., Kozlik L., Scapozza C., 2007. A method for assessing "scientific" and "additional values" of geomorphosites. Geographica Helvetica 62: 148-158.

Richling A., 1992. Kompleksowa geografia fizyczna. Wyd. Nauk. PWN, Warszawa.

Richling A., Solon J., 2011. Ekologia Krajobrazu. Wyd. Nauk. PWN, Warszawa.

Ruban D.A., 2010. Quantification of geodiversity and its loss. Proceedings of the Geologists' Association 121: 326-333.

Saaty T. L., 1977. A Scaling Method for Prioritiesin Hierarchical Structures. Journal of Mathematical Psychology 15: 234-281.

Saaty T. L., 1980. The analytic hierarchy process. McGraw-Hill, New York.

Saaty T. L. 1994. Fundamentals of Decision Making. RSW Publications.

Saldaña A., Ibáñez J.J., 2004. Pedodiversity analysis at large scales: an example of three fluvial terraces of the Henares River (central Spain). Geomorphology 62: 123-138.

Serrano E., Ruiz-Flaño P., 2007. Geodiversity. A theoretical and applied concept. Geographica Helvetica 62: 1-8.

Serrano E., Ruiz-Flaño P., 2009. Geomorphosites and Geodiversity. W: E.Reynard, P.Coratza, G.Regolini-Bissig (red.), Geomorphosites. Verlag Pfeil, Munich, s.: 51-63.

Serrano E., Ruiz-Flaño P., Arroyo P., 2009. Geodiversity assessment in a rural landscape: Tiermes-Caracena area (Soria, Spain). Memorie Descrittive Della Carta Geoligica d'Italia 87: 173-180.

Sharples C., 1993. A Methodology for the Identification of Significant Landforms and Geological Sites for Geoconservation Purposes. Tasmania, Australia, Forestry Commission.

Sharples C., 1995. Geoconservation in forest management - principles and procedures. Tasforests 7: 37-50.

Sharples C., 2002. Concepts and Principles of Geoconservation (Version 3). Department of Primary Industries, Parks, Water and Environment, Tasmania.

Sidorczuk M., Ścibisz-Kosanowska M., 2013. Georóżnorodność Warmii i Mazur. Wydawnictwo Mantis. Olsztyn. 
Silva J.P., Pereira D., Aguiar A.M., Rodrigues C., 2013. Geodiversity assessment of the Xingu drainage basin, Journal of Maps 9(2): 254-262.

Silva J.X., 2004. Geodiversity: Some simple geoprocessing indicators to support environmental biodiversity studies. Online: www.directionsmag.com/articles/geodiversity-some-simple-geoprocessingindicators-to-support-environmental-/123803 - 09.08.2014.

Sołowiej D., 1992. Podstawy metodyki oceny środowiska przyrodniczego człowieka. Wydawnictwo Naukowe UAM, Poznań.

Stanley M., 2001. Geodiversity strategy. Progeo News 1: 6-9.

Testa B., Aldighieri B., Bertini A., Blendinger W., Caielli G., De Franco R., Giordano D., Kustatscher E., 2013. Geomorphodiversity of the San Lucano Valley (Belluno Dolomites, Italy): a Well-Preserved Heritage. Geoheritage 5(3): 151-172.

Virtanen R., Luoto M., Rämä T., Mikkola K., Hjort J., Grytnes J-A., Birks H.J.B., 2010. Recent vegetation changes in the high-latitude tree-line ecotone are controlled by geomorphological disturbance, productivity and diversity. Global Ecology and Biogeography 19: 810-821.

Wiedenbein F.W., 1993. Ein Geotopschutzkonzept für Deutschland. W: Geotopschutz Probleme: der Methodik und der Praktischen. Saarbrucken, Germany, University of Saarland.
Wróblewski T., 2000. Ochrona georóżnorodności w Regionie Świętokrzyskim z Mapą chronionych obszarów i obiektów przyrody nieożywionej 1:200 000. Min. Środ. i Państ. Inst. Geol., Warszawa.

Zadeh L. A., 1965. Fuzzy sets. Information and Control 8(3): 338-353.

Zhang X., Chen J., Zhang G., Tan, M., 2003. Pedodiversity analysis in Hainan Island. Journal of Geographical Sciences 13 (2): 181-186.

Zwoliński Zb., 2004. Geodiversity. W: A.S.Goudie (red.), Encyclopedia of Geomorphology, Vol. 1, Routledge, s.: 417-418.

Zwoliński Zb., 2007. Georóżnorodność rzeźby Polski - metodologia i metodyka. Online: geoinfo.amu.edu.pl/gi/gisday2007/032007-GISDay-Zwolinski-geodiv-pdf.pdf - 09.08.2014.

Zwoliński Zb., 2008. Designing a map of the geodiversity of landforms in Poland. IAG and AIGEO International Meeting Environmental Analysis and Geomorphological Mapping for a Sustainable Development, Addis Ababa, Ethiopia, February 26, 2008.Abstract Book s.: $18-22$.

Zwoliński Zb., 2009. The routine of landform geodiversity map design for the Polish Carpathian Mts. W: E. Rojan, A. Łajczak (red.), Geoecology of the Euroasiatic Alpids. Landform Analysis 11: 79-87.

Zwoliński Zb., 2010. Aspekty turystyczne georóżnorodności rzeźby Karpat. Prace Komisji Krajobrazu Kulturowego PTG 14: 316-327.

Zwoliński, Zb., Stachowiak J., 2012. Geodiversity map of the Tatra National Park for geotourism. Quaestiones Geographicae 31(1): 99-107. 